\title{
A epidemiologia como instrumento de transformação
}

A expressão "O Homem e o Meio" tem sido amplamente utilizada no sentido ecológico mais restrito, no qual o ecológico está limitado ao componente físico-biológico do ambiente no qual vive o Homem. Quando muito, os outros componentes do meio, os relacionados com o social, o econômico e o cultural, são tratados, concessivamente, como mais alguns elementos analisáveis, separadamente, ao lado dos demais componentes acima referidos.

Essa noção ecológica limitada, e conseqüentemente nada holística, vem servindo a interesses políticos, econômicos e expansionistas, através de teorias elaboradas nos países desenvolvidos. Assim, a noção de "espaço", construída pela geografia clássica, dominou até o início da década de 50 , quando, pela primeira vez, $P$. George deu início ao processo de sua renovação, emprestando-lhe um novo conceito dinâmico e dialético de "situação" no qual foi introduzida a noção de contradição como propulsora da dinâmica social.

A partir daí, um novo conceito de "espaço" vem sendo desenvolvido, vindo a se constituir no fundamento da Nova Geografia. De uma geografia ligada à história dos homens e suas relações com o meio natural.

Isso significa uma história de luta do Homem em busca de sua identidade em relação ao meio hostil que ele procura modificar em seu justo proveito, respondendo, assim, à sua aspiração de libertação para a vida plena que "... é a promessa do Deus bíblico".

Esses conceitos da geografia se aplicam à evolução que vem sofrendo a epidemiologia em seus esforços de procurar esclarecer a causação das doenças e as relações entre o ambiente natural e aquele modificado pelo próprio homem. Estas "situaçōes" podem ser traduzIdas em termos de relaçб̃es saúde/doença, quando aos dois termos deste binômio se lhes emprestam os significados histórico e epistemológico.

Como na geografia clássica, o conceito de saúde/doença foi sempre assentado sobre o suposto equilibrio entre 0 homem e o seu meio natural. Neste sentido, a "História Natural da Doença", elaborada, impressa e difundida no mundo inteiro, vem servindo como tex to didático em todas as escolas de saúde, em todos os níveis.

Como na geografia, os elementos naturais foram utilizados como totalidade climática para distinguir os homens: foi criada a "medicina tropical", para "justificar" as enormes desigualdades, sociais e econômicas que distinguem os Cadernos de Saúde Pública, R.J., 1 (2) :137-139, abr/jun, 1985. 
homens que habitam regiões subdesenvolvidas daqueles que usufruem conforto e bem-estar nas regiões desenvolvidas.

A visão acima - conformista e não-dialética - baseada no espiritualismo do século passado, deve ceder à concepção de uma nova epidemiologia que se posiciona contra as fatalidades ditas "naturais" ou "tropicais" e que pretende contribuir para o aperfeiçoamento do Homem. O que modela a saúde dos povos não são os elementos naturais, mas as desigualdades econômicas.

A epidemiologra moderna segue os mesmos caminhos da nova geografia. Dominada pela infectuologia, a epidemiologia utilizou durante muitos anos um modelo linear unicausal. Esse modelo foi evoluindo até alcançar sua forma atual, multicausal, na qual os determinantes da doença são hierarquizados.

Em conseqüência do modelo acima, foi possivel distinguir dois campos interligados de estudo, um chamado de macroepidemiologia e outro de microepidemiologia. $\mathrm{O}$ primeiro é capaz de explicar o processo saúde/doença através de elementos mais abrangentes das análises histórica, econômica e social, hoje incluido na rubrica interdisciplinar de geografia social. O segundo, utilizando os métodos epidemiológicos clássicos, estuda o mesmo fenômeno saúde/ doença em grau de detalhamento que escapa aos métodos da macroepidemiologia. Apesar dessa aparente separação entre dois campos de estudo, a epidemiologia mantém sua identidade.

Como na geografia atual, os determinantes maiores da doença podem ser analisados dentro da paisagem organizada pelo homem em sua concretude histórica.

Como disciplina de estudo, a Epidemiologia constitui o mais abrangente campo do conhecimento humano na área de saúde. Sua abrangência lhe é conferida pela sua macrovisão dos fenômenos vitais em termos coletivos.

Utilizando metodologias as mais avançadas de disciplinas correlatas, a Epidemiologia ganhou outra dimensão, o que lhe permite questionar os determinantes maiores das doenças, discutir problemas relacionados com o planejamento e a adequação dos serviços de saúde, informar aos médicos clínicos que tal ou qual processo terapêutico ganhou ou não status de eficiência comprovada.

O pensar epidemiológico é hoje necessário não apenas a os epidemiologistas, mas a todos os profissionais da área da saúde e mesmo aos leigos. Estes se deparam no noticiário cotidiano com expressões francamente epidemiológicas quando. por exemplo, os jornais noticiam estudos controlados mostrando significância ou não de determinados dados coletados em amostras de população. Assuntos que tocam diretamente a vida do Homem, como o papel do fumo so- 
bre a saúde ou o uso de anticoncepcionais, são debatidos através dos meios usuais de informação.

$O$ conceito atual de interdisciplinaridade remete o pensamento crítico e criador para alturas jamais imaginadas pelos pesquisadores do passado. Nenhuma disciplina pode existir plenamente sem que, sadia e sabiamente, invada territórios antes julgados intransponíveis. Com esta atitude do pensar, o conhecimento ganha em profundidade e extensão.

Mas a epidemiologia vai além de um simples instrumento de análise. Ela penetra profundamente no âmago dos problemas mais relevantes da vida humana. Nesse sentido, ela se situa, como as ciências sociais, como instrumento valioso de transformação social.

O que situa a Epidemiologia como instrumento transformador é exatamente sua macrovisão dos problemas de saúde, o que só foi possivel com sua intromissão em terrenos até há pouco considerados independentes e isolados.

$O$ papel transformador da Epidemiologia se coloca diante de sua capacidade de conhecer a realidade, de questionar as organizações sociais e econômicas de um país ou região e seu relacionamento com as condições de saúde da população. E, particularmente, de ser capaz de propor medidas transformadoras que venham melhorar o estado de saúde e bem-estar de determinada sociedade.

Antes de ser um instrumento para medir sadicamente 0 sofrimento humano, a epidemiologia projeta-se para o futuro como a ecologia da saúde, comprometida com o bem. estar social.

Frederico Simões Barbosa 